\title{
Recorregut de recerca geològica i mineralògica per les comarques del Solsonès i de l'Alt Urgell: des de Cambrils a Llinars, Alinyà, la Vall del mig, Perles, al Pont d'Espia i a Fígols d'Organyà
}

Josep Maria Mata-Perelló

Joaquim Sanz Balagué

\section{XARAGALL \\ REVISTA DE CIÈNCIES DE LA CATALUNYA CENTRAL}

\section{n. 3}

$\operatorname{març} 2014$ 


\title{
RECORREGUT DE RECERCA GEOLÒGICA I MINERALÒGICA PER LES COMARQUES DEL SOLSONÈS I DE L'ALT URGELL: DES DE CAMBRILS A LLINARS, ALINYÀ, LA VALL DEL MIG, PERLES, AL PONT D'ESPIA I A FIGOLS D'ORGANYÀ
}

\author{
Josep Maria Mata-Perelló \\ Museu de geologia Valentí Masachs, Escola Politècnica Superior d'Enginyeria de Manresa \\ (EPSEM), Universitat Politècnica de Catalunya · BarcelonaTech (UPC), 08272 Manresa, Spain
}

\section{Joaquim Sanz Balagué}

Departament d'Enginyeria Minera i Recursos Naturals (EMRN), Escola Politècnica Superior d'Enginyeria de Manresa (EPSEM), Universitat Politècnica de Catalunya · BarcelonaTech (UPC), 08272 Manresa, Spain

Paraules clau: mantell de Bóixols; carst; Keuper

\section{Resum}

Sortida realitzada el dia 16 de febrer del 2013. En aquesta ocasió, el recorregut de l'itinerari discorre íntegrament per una de les unitats geològiques que es distribueixen per Catalunya; concretament es transitarà pel Sistema Pirinenc.

Així, el recorregut de l'itinerari recalarà sempre per la zona antigament denominada "prepirineu", és a dir: pel les actualment dites Zones Sudpirenenques. Així, en bona part del recorregut es tallarà el Mantell de Bóixols (entre Cambrils i la fi del recorregut, a Fígols d'Organyà). També es tallaran diversos sectors tangencials del Mantell del Montsec i del de les Serres Marginals. Tot aquest recorregut pels Pirineus, s'efectuarà gairebé entre Cambrils i l'esmentada població de Fígols d’Organyà.

Per d'altra banda, el recorregut de l'itinerari, es distribueix per dues comarques: el Solsonès i I'Alt Urgell. Així, s'iniciarà dintre de la primera, al terme de Cambrils, per a finalitzar a la segona comarca al poble de Fígols d'Organyà, molt prop de les poblacions d'Organyà (a l'Oest) i de Coll de Nargó (al Sud). 


\section{Objectius generals}

Es concretaran en diversos aspectes, geològics i mineralògics que apuntarem a continuació:

1.- Estudi i observació dels materials mesozoics i cenozoics dels relleus prepirinencs meridionals, que corresponen al Mantell del Bóixols (que es talla entre les poblacions de Cambrils i les immediacions de la de Fígols d'Organyà) i també de Mantell del Montsec. En aquest recorregut, els materials mesozoics que anirem trobant $s$ es distribueixen entre el Triàsic, el Juràssic i el Cretàcic; mentre que els cenozoics pertanyen quasi exclusivament a l'Eocè.

2.- Observació de les estructures dels mantells acabats d'esmentar, dintre del paràgraf anterior; així com dels contactes que tenen entre sí, al llarg dels trams finals del recorregut.

3.- Reconeixement de diverses mineralitzacions que anirem veient al llarg del recorregut.

3A) les mineralitzacions evaporítiques (de GUIX i d'HALITA), situades al terme de Cambrils (Solsonès), entre els materials triàsics del Keuper, a la unitat del Mantell de Bóixols.

3B) o com les mineralitzacions ferruginoses associades a formacions lignitíferes cretàciques, de Santa Pelaia (Alt Urgell). Aquestes mineralitzacions es situen entre dels afloraments cretàcics del Mantell de Bóixols.

3C) les mineralitzacions de rebliment de cavitats càrstiques, situades a la Vall del Mig (Alt Urgell), amb minerals i roques alumíniques (bauxita). Aquestes mineralitzacions es situen entre els afloraments mesozoics (del Juràssic i del Cretàcic Inferior), dintre del Mantell de Bóixols.

4.- Observació de diferents explotacions mineres al llarg del recorregut, sobre tot de les relacionades amb les mineralitzacions acabades d'esmentar al punt anterior.

5.- Observació dels diferents indrets amb important risc geològic, que anem trobant al llarg del recorregut. Dintre d'aquest apartat, cal fer esment de:

5A) de les dolines desenvolupades a diferents indrets dels camps de Cambrils, per dissolucions dels materials del Keuper

5B) de les ondulacions desenvolupades a la carretera de Cambrils a Alinyà, en haver-se construït sobre els materials del Keuper

6.- Observació dels diferents indrets que anem trobant, al llarg del recorregut, relacionats amb el Patrimoni Geològic. Dintre d'aquest, cal fer esment de:

$6 \mathrm{~A})$ del relacionat amb les surgències d'aigua salada, situades entre els materials del Keuper, prop de Cambrils.

6B) I'Anticlinal de I'Alinyà, que veurem des de diversos indrets del recorregut, tot formant part del Mantell de Bóixols

6C) de les bossades de rebliment càrstic, amb bauxita. Les trobarem a les immediacions de I'Alzina i de la Vall del Mig, dintre dels materials del Mantell de Bóixols.

7.- Observació dels diferents indrets que anem trobant, al llarg del recorregut, relacionats amb el Patrimoni i Miner. Dintre d'aquest apartat, cal fer especial esment de les antigues Salines de Cambrils. 


\section{Antecedents}

En relació a aquest recorregut, existeixen uns altres antecedents nostres (MATA-PERELLÓ, 1995a, 1995b, 1996, 1998, 2001, 2003, 2004, 2005, 2006, 2009, 2010 i 2012), els quals segueixen uns recorreguts sensiblement iguals al present, amb unes petites variacions en cada cas. Igualment, farem esment de l'existència d'un recull d'itineraris propers al present, dintre del treball de MASACHS et altri (1981).

Pel que fa a les mineralitzacions que veurem en aquest itinerari, cal dir que ja estat prèviament descrites per nosaltres en diversos treballs; entre ells farem esment de MATA-PERELLÓ (1984 i 1990). I, finalment, pel que fa a les característiques de l'estructura geològica, dels indrets per on discorrerà el recorregut del present itinerari, ens remetrem a RIBA et altri (1976), i a GUIMERÀ et altri (1992).

Tots aquests treballs esmentats, i d'altres, figuraran a l'apartat dedicat a les REFERÈNCIES BIBLIOGRÀFIQUES, al qual ens remetem.

\section{Descripció del recorregut de l'itinerari}

El recorregut del present itinerari s'inicia al terme de Cambrils, per on s'efectuaran diverses aturades. A continuació l'itinerari seguirà cap a Llinars, (per la carretera local que uneix la població solsonenca de Sant Llorenç de Morunys amb el Pont de l'espià, i després amb la poblacions alt urgellenques de Coll de Nargó i Organyà. Poc després de deixar Llinars, es farà una fillola cap a ponent, per tal d'anar cap a les Mines de Lignit de Santa Pelaia, de l'antic terme d'Alinyà. Així, en aquest tram del recorregut es passarà de la comarca del Solsonès a la de l'Alt Urgell.

Després, i per la mateixa carretera anterior, es continuarà cap al poblet de les Sorts (en un recorregut aproximat de $10 \mathrm{Km}$, des de Cambrils). Tot seguit caldrà continuar des de les Sorts cap a la Vall del Mig, per carretera local que es dirigeix cap a l'Alzina, en un recorregut de quasi $5 \mathrm{Km}$, tot fent una fillola. A la Vall del Mig es farà una nova aturada. Finalment, el recorregut es dirigirà cap al Pont de l'espià, des d'on s'anirà cap a Fígols d'Organyà, per on es farà la darrera aturada d'aquest itinerari.

\section{Advertiment previ}

Com en altres recorreguts de recerca geològica i mineralògica ..., si es disposa del temps suficient, poden efectuar-se passant per totes les parades i filloles. En cas contrari, recomanem prescindir de les anomenades parades - condicionals.

Com de costum, creiem oportú de recomanar, que alhora d'efectuar el recorregut de l'itinerari es cerqui la informació més àmplia possible sobre l'estat dels trams del recorregut a realitzar, tant per pistes forestals, com per carreteres en mal estat de conservació. Tot i així, en aquest cas, tots els trams es faran per carreteres.

També recomanem tenir el màxim respecte de cara a la conservació del Medi Natural i del Medi Ambient, en tot moment, tant al llarg del recorregut d'aquest itinerari, com fora d'ell. 


\section{Descripció de l'itinerari}

En aquest recorregut hem situat una sèrie d'estacions o de parades, que anirem veient a continuació. En cada cas, els hi donarem una denominació que podrà correspondre a algun paratge proper. Per d'altra banda, entre parèntesi, indicarem el número del "Mapa Topográfico", dels mapes de la Cartografia Militar de España, a escala 1:50.000, on es troba situada la parada considerada, i que serà algú dels tres següents: 253 (o d’Organyà), 291 (o d'Oliana) 0 292 (o de Sant Llorenç de Morunys). Així doncs, la relació ordenada de les aturades que constitueixen el recorregut de l'itinerari, és la següent:

\subsection{Parada 1. Salines de Cambrils. (Cambrils, terme municipal d'Odèn, comarca del Solsonès). (Full 291)}

El recorregut de l'itinerari, caldrà començar-lo en aquest indret, a poc més de 0’5 Km des de la carretera i a poc més de 1'5 Km del poble.

Quasi tot el recorregut, des del poble, s'efectua per entre els materials del Keuper. Precisament, les salines es troben sobre un aflorament d'aquests materials triàsics, constituïts per nivells de guixos i d'argiles.

Les salines es relacionen amb la presència de fonts d'aigua salada. Les aigües han circulat entre els materials triàsics, i han dissolt la sal present en ells. Després, en arribar a la superfície, s'evapora l'aigua i es precipiten els materials dissolts. Entre els minerals presents, cal parlar de la presència d'HALITA, normalment acompanyada de GUIX. A l'actualitat, el primer apareix formant unes eflorescències força paleses.

És també força interessant, observar les basses d'evaporació, graonades per tota la muntanya, aprofitant al màxim les poques superfícies planes que el relleu ofereix. En aquest sentit, aquestes constitueixen el millor exemple de les anomenades "salines de muntanya" de tot Catalunya. (fotografies 1 i 2 ).

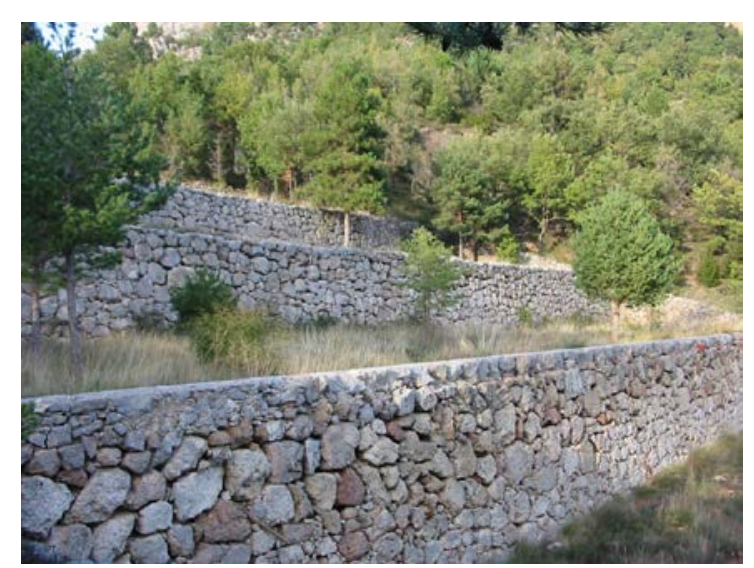

Fotografia 1.Distribució de les salines en bancades

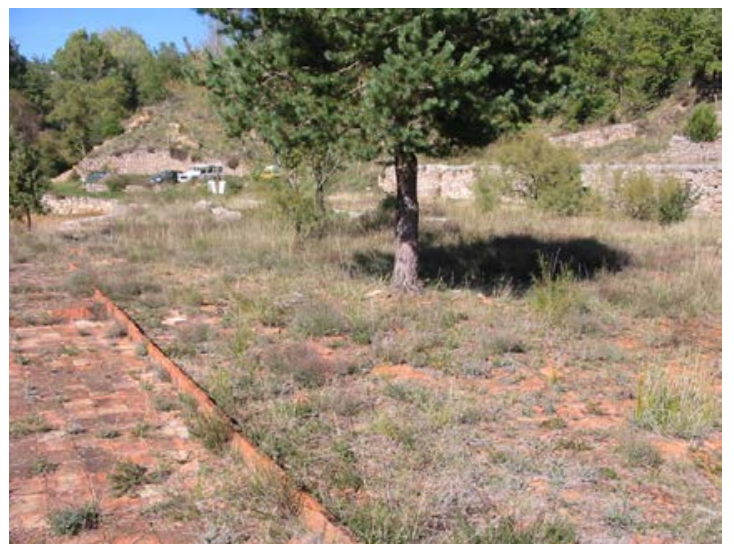

Fotografia 2.Les salines de la part alta

Cal també tenir en compte que aquestes salines van gaudir duna certa importància, (especialment durant el segle XVIII), i que a l'actualitat es troben davant d'uns tímids intents de restauració.

També, des d'aquest indret, i mirant cap a l'Oest, i cap a l'OSO, es pot veure una estructura similar a la descrita a la parada anterior, amb l'encavalcament abans esmentat. 
Per d'altra banda, en aquest indret hi ha també una línia d'aprofitament de l'aigua dolça, amb una sèrie de canalitzacions que uneixen els diferents molins situats a la riba dreta de riu salat. Aquests molins també han estat recentment restaurats.

\subsection{Parada 2. L'esllavissada de Cambrils, (Cambrils, terme municipal d'Odèn, comarca del Solsonès). (Full 291)}

Després de fer l'aturada anterior, cal anar cap a Cambrils, tot anant per la carretera local que va cap al Coll de Jou i (cap a Sant Llorenç de Morunys). Cal recórrer quasi $1 \mathrm{Km}$ des de la parada anterior. En arribar a la esllavissada farem una nova aturada.

En aquest indret, i mirant per sobre de la carretera, es poden veure les restes de l'espectacular esllavissada dels materials calcaris cretàcics de la Serra de la Tosa de Cambrils, succeïda fa uns tres segles.

A l'actualitat hi ha un perill imminent de noves esllavissades, doncs tota la roca es troba fracturada, per sobre de Cambrils i de la carretera. Prop d'aquesta es troben uns espectaculars blocs. Aquests blocs també es troben per sobre de les cases i del proper poliesportiu. ( fotografia 3).

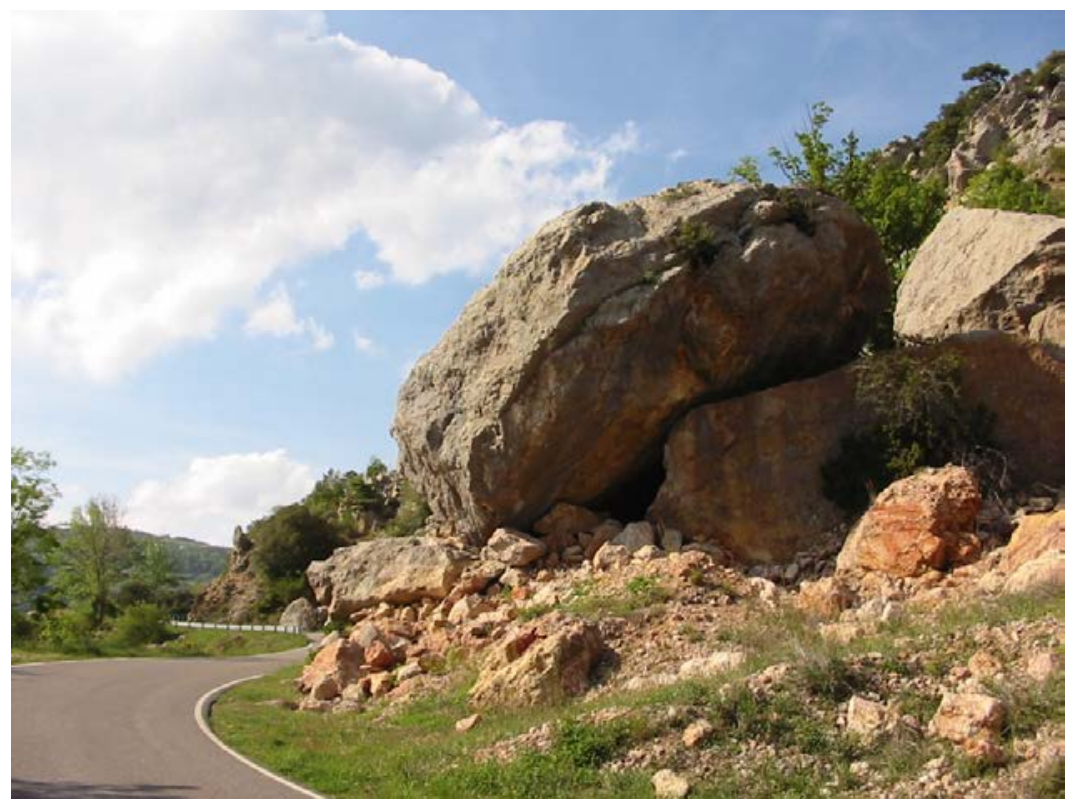

Fotografia 3. Un aspecte dels blocs caiguts sobre la carretera

\subsection{Parada 3 - Condicional. Per sobre del poble, (Cambrils, terme d'Odèn, comarca del Solsonès). (Full 291)}

Després de fer la parada anterior, cal arribar cap el poble de Cambrils. En arribar-hi i sobrepassar-lo, trobarem un camí que puja a unes penyes situades per sobre del poble. Aquí farem una nova aturada, a uns 1'2 $\mathrm{Km}$ de l'anterior. 
En aquest recorregut, hem continuat trobant blocs despresos i caiguts sobre el camí i sobre la carretera. Tot i això, en aquest indret veurem un aflorament de calcàries molt fracturades i amb unes grans diàclasis. Aquests es troben obertes sobre el poble, provocant un gran risc

\subsection{Parada 4. Les cabanes de pagès, (Cambrils, terme d'Odèn, comarca del Solsonès). (Full 291)}

Després de fer la parada anterior, cal retornar cap el poble de Cambrils. En arribar a I'Ajuntament, encara cal continuar una mica. Més enllà es pot fer una nova aturada en alguna de les cabanes de pagès. En tot cas, haurem fet un recorregut proper als $2 \mathrm{Km}$, des de la darrera parada.

En aquest recorregut, hem circulat en bona part entre els materials triàsics del Keuper, amb afloraments de guixos i argiles. Sovint, la carretera s' ha esllavissat en situar-se sobre aquests materials. Aquest esquerdament de la carretera es pot veure en nombrosos indrets de la mateixa.

Alhora, en aquest recorregut, s'han fet paleses moltes bòfies pels camps propers, alguna d'elles molt propera a l'Ajuntament, per sobre del mateix, en uns camps.

Després, en arribar a l'indret de l'aturada (en cas d'haver demanat permís i d'haver-lo obtingut), es pot veure com els pagesos han aprés a utilitzar les grans esquerdes que produït les esllavissades, convertint-les en cabanes, on es poden conservar gran nombre d'aliments. (fotografies 4 i 5).

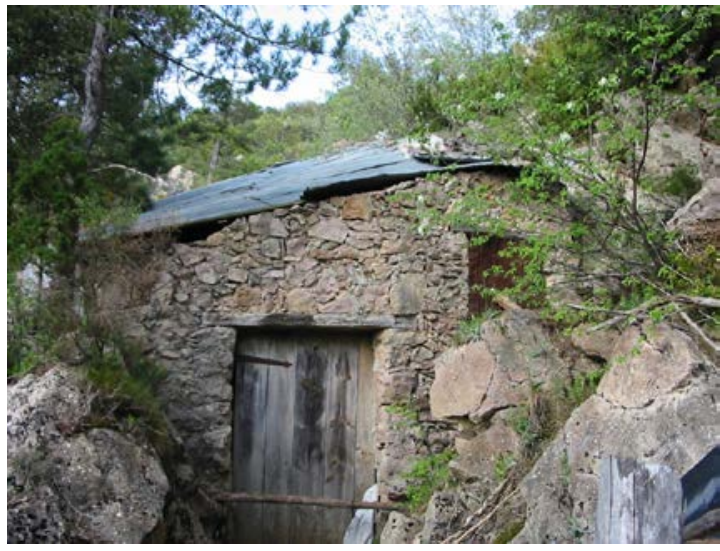

Fotografia 4. Entrada a una de les cabanes

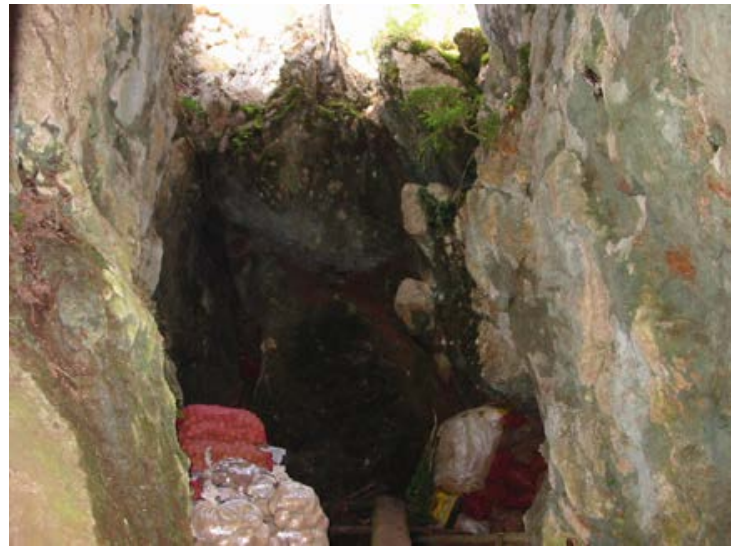

Fotografia 5. Interior d'una de les cabanes

Un altre aprofitament, és el que realitzen els dos restaurants de la zona. Consisteix en l'extracció d'aire fred a l'estiu; i d'aire calent a l'hivern.

\subsection{Parada 5. Mina de lignit de Santa Pelaia (Perles, terme municipal de Fígols - Alinyà, comarca de l'Alt Urgell). (Full 291).}

A continuació, després d'efectuar la parada anterior, cal retrocedir cap al poble de Cambrils. per a continuar després cap a Alinyà, passant per Linya, per la carretera que uneix Sant Llorenç de Morunys amb Organyà. 


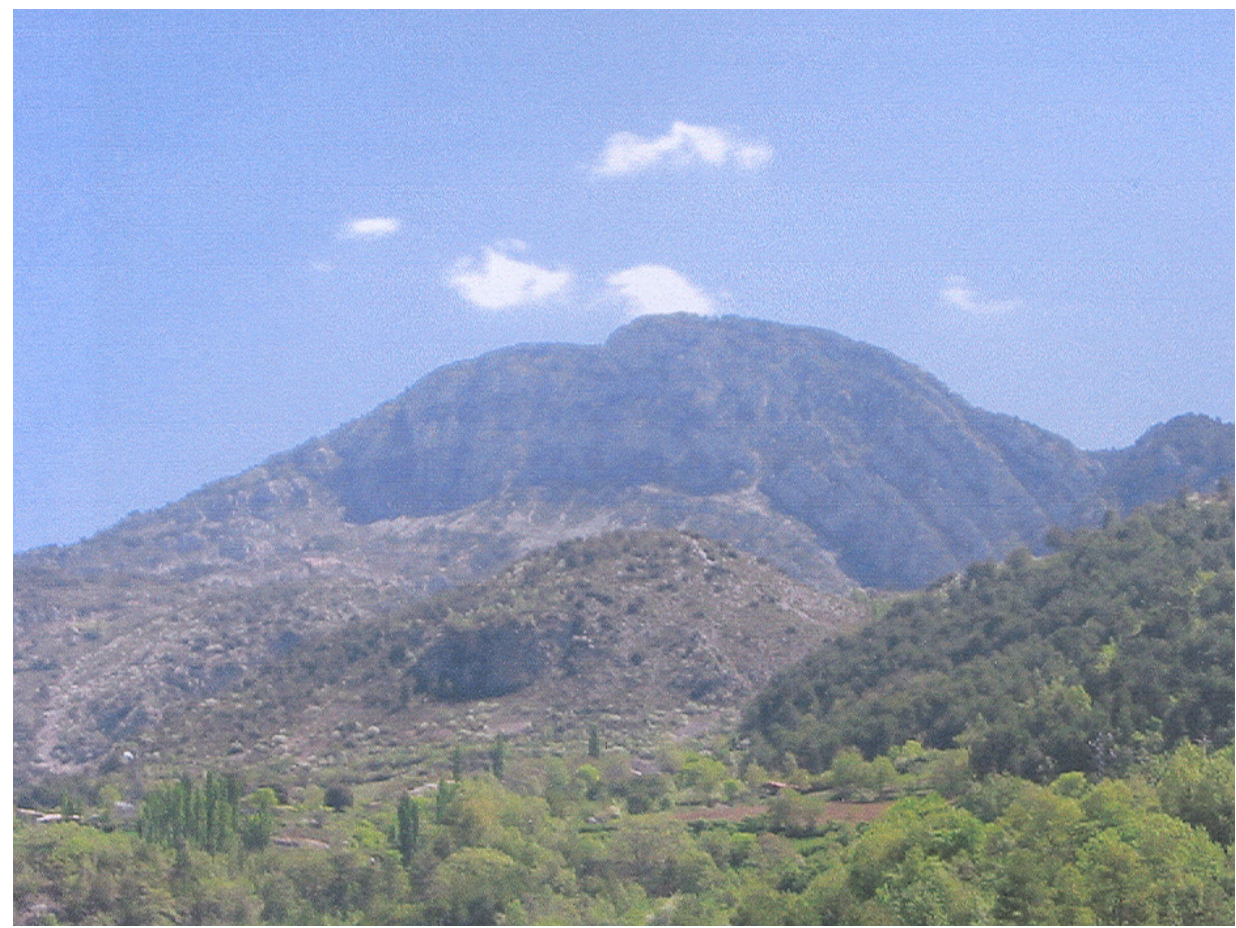

Fotografia 6. Un aspecte de I’Anticlinal d'Alinyà

En un recorregut d'uns $3 \mathrm{Km}$, i després de traspassar el límit comarcal, es troba (per l'esquerra de la carretera) el camí que condueix cap a la Mina de Lignit de Santa Pelaia. Aquest camí parteix del Km 16,6 de la carretera abans esmentada. En aquestes mines, és on ens cal fer la present aturada, després d'un recorregut proper als $5 \mathrm{Km}$, des de la parada anterior.

En aquest recorregut des de Cambrils, es van travessant els materials del Mantell del Cadí Port del Compte; i es fan paleses diverses fractures i petits encavalcaments, la qual cosa fa que els materials del Keuper, apareixen diverses vegades. a la vora de la carretera. Concretament, en aquest tram, es travessa la zona d'encavalcament del Mantell del Cadí Port del Comte, per part del Mantell del Montsec.

Pel que fa a les mines, es localitzen sobre els materials d'aquest darrer mantell (que forma part de la Unitat Sud-pirinenca Central, i que aquí constitueix l'extrem oriental de la Serra de Turb). Així, els nivells de lignits es situen en un aflorament dels materials del Cretàcic Mig, i més concretament del trànsit de l'Albià al Cenomanià. (fotografia 6).

Els lignits han estat intentats d'ésser explotats, tant per mineria subterrània com per mineria a "cel obert", en tots els casos, sense gaire èxit. Actualment aquesta mineria es troba totalment aturada, i en bona part sotmesa a un procés creixent de descoronament Tot i així, en els darrers anys la s'ha treballat en la restauració d'aquesta zona, per la Fundació Territori i Paisatge. Aquest treball ha contribuït encertadament a recuperació paisatgística d'aquesta zona.

Entre els nivells carbonosos es troben abundants mineralitzacions ferruginoses, amb presència de PIRITA, com a mineral primari. Aquest mineral ha donat lloc a la formació de: GOETHITA (d'aspecte terròs i limonític), HEMATITES, SIDERITA i MELANTERITA.

També hi ha presència d'altres sulfats, com el SIDEROTíl i la FERROHEXAHIDRITA. Finalment, cal dir que també hi ha presència d'altres minerals com la CALCITA i el GUIX. 


\subsection{Parada 6 - Ccondicional. Immediacions del $\mathrm{Km} \mathrm{14,1}$ de la carretera, cap al Pont d'Espia, (les Sorts, terme de Fígols-Alinyà, comarca de l'Alt Urgell). (Full 253)}

Des de la parada anterior, cal retornar a la carretera, per tal de continuar cap a Alinyà, baixant cap a la vall del Riu Perlés. Caldrà parar cap a les immediacions del Km 14'1. Aquest indret, on efectuarem la present aturada, es troba a uns 2' $5 \mathrm{Km}$ de la parada anterior.

Des d'aquest indret es pot observar el grandiós Anticlinal d'Alinyà, que forma part del Mantell de Bóixols, que a l'altra banda del Riu Perlés encavalca al Mantell del Montsec, pel qual ara anem circulant.

\subsection{Parada 7. Mines $i$ afloraments de bauxita de la Vall del Mig (la Vall del Mig, terme de Fígols - Alinyà, comarca de l'Alt Urgell). (Full 253)}

A partir de la parada anterior, cal continuar cap a Alinyà. A uns $4 \mathrm{Km}$ es troba el poble de les Sorts, i immediatament a continuació (cap el $\mathrm{Km} \mathrm{10}$ '8) el trencall que porta a I'Alzina i a la Vall del Mig. Cal agafar-lo, i en un recorregut d'uns $4 \mathrm{Km}$, per aquest trencall asfaltat, s'arriba a la Vall del Mig. En aquest darrer indret, situat a uns $8 \mathrm{Km}$ de la parada anterior, és on ens cal fer la present aturada.

En aquest indret es troben uns interessants afloraments de bauxites. Aquestes es troben reblint cavitats d'origen càrstic, situades entre uns afloraments de calcàries mesozoiques, que pertanyen al Cretàcic Inferior dintre del Mantell de Bóixols

Entre els minerals pressents a les bauxites, cal fer esment dels següents: BOEHMITA, DIASPOR i GIBBSITA. També cal fer esment de la CAOLINITA, entre els minerals d'alumini. També hi és present I'ALUMOGEL, un òxid mineraloid d'alumini. Per d'altra banda, cal destacar la notable presència de minerals de ferro, com els següents: GOETHITA (sempre terrosa i limonítica) i HEMATITES. Un altre mineral present, és la CALCITA.

Són de destacar els bonics exemples de rebliment de cavitats d'origen càrstic. Aquests afloraments, cal dir que constitueixen un indret singular, digne de formar part del nostre Patrimoni Geològic, per dret propi.( fotografies 7 i 8). 


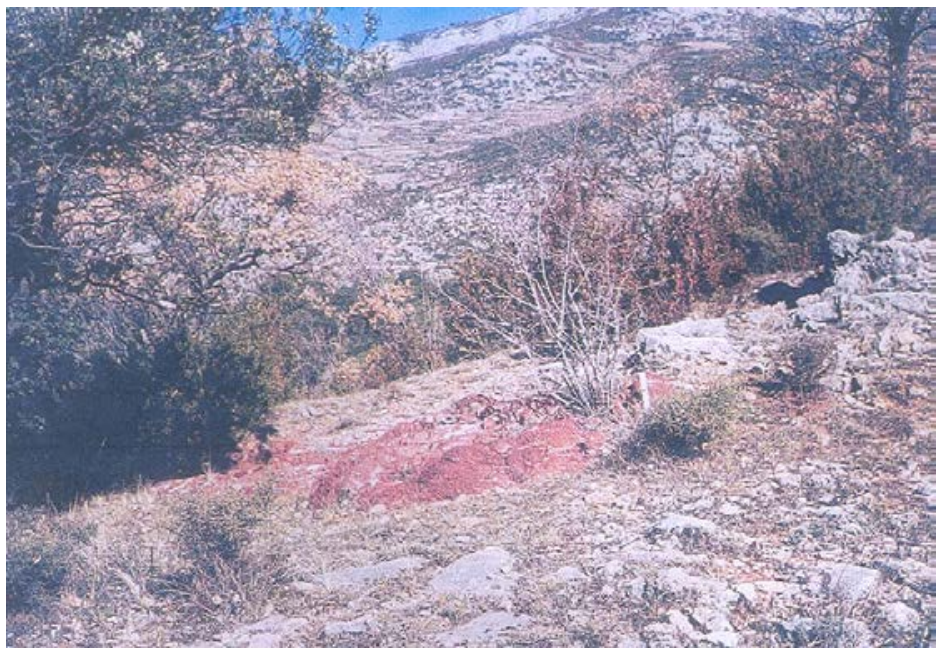

Fotografia 7. Aspecte de la bossada càrstica de la Vall del Mig

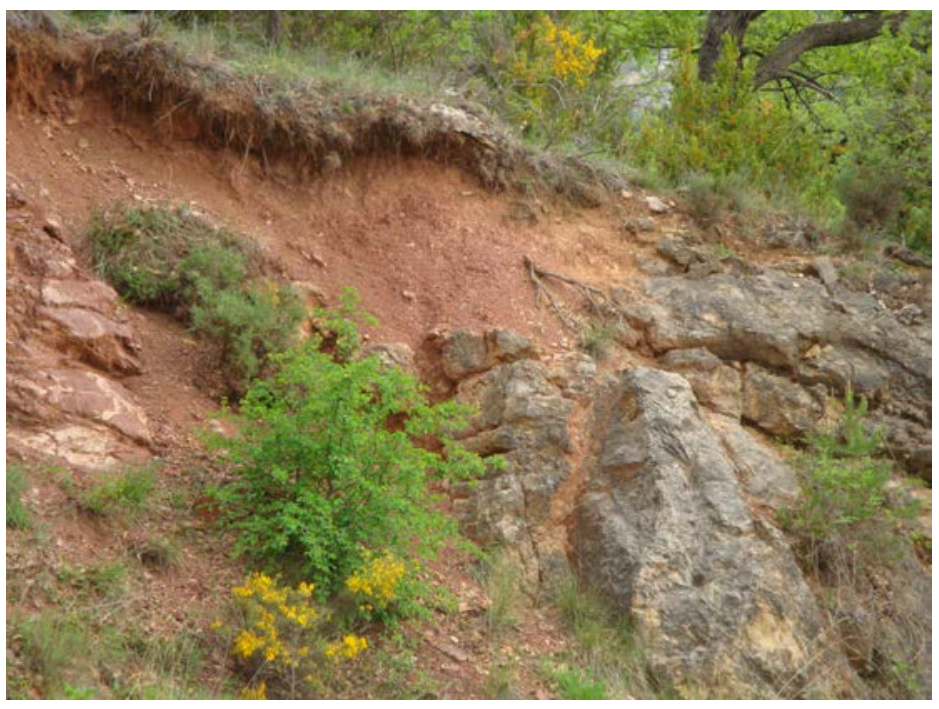

Fotografia 8. Aspecte de la bossada càrstica de la Vall del Mig, al tall de la carretera

\subsection{Parada 8 - Condicional. Pont de l'Espià, (termes municipals de Coll de Nargó i de Fígols - Alinyà, comarca de I’Alt Urgell). (Full 253)}

Des de la parada anterior cal tornar a les Sorts. Des d'aquí, cal anar cap a l'Oest, passant successivament per: Alinyà, Perles, Canelles i el Palau. Tot seguit, s'arribarà al Pont de I'Espia. En arribar a l'esmentat pont serà necessari no passar-lo, i agafar la nova carretera que es dirigeix directament cap Fígols d'Organyà, per la dreta del Riu Segre, en sentit ascendent. En aquest indret farem la darrera aturada, a la vora del riu.

En el trajecte des d'Alinyà fins al Pont de I'Espia es van tallant els materials margosos del Cretàcic Superior, que van alternant amb nivells calcaris i gresosos, amb tonalitats grisgroguenques per a tot el conjunt. 
En arribar a Perles, es pot veure I'antiga explotació de nivells carbonosos de Santa Pelaia (que hem vist anteriorment a la PARADA 5). També, i al SSW, es pot observar la "foradada", excavada entre els materials calcaris cretàcics.

Després en arribar a la vall del Riu Segre, s'entra en l'ampla depressió morfològica de la Ribera d'Organyà, excavada entre els materials calcolutítics del Cretàcic Inferior i del Cretàcic Mig. Precisament, des de l'indret de la parada, es pot gaudir d'un bon lloc d'observació d'aquesta cubeta d'erosió.

\subsection{Parada 9. Esglèsia de Figols d'Organyà (terme de Fígols d'Organyà - Alinyà, comarca de l’Alt Urgell). (Full 253)}

Després de la parada anterior al Pont de l'Espia. Cal agafar la carretera que es dirigeix cap al veí poble de Fígols d'Organyà. En arribar-hi, s'efectuarà una breu parada al turó de l'Església, després d'efectuar un recorregut molt proper als $6 \mathrm{Km}$, des de la parada anterior, per tal $d^{\prime}$ arribar fins on ara ens trobem.

Així, en tot aquest recorregut s'han tallat afloraments de materials mesozoics, que en la seva major part pertanyen al Mantell de Bóixols, i es comencen a trobar materials eminentment calcaris del Cretàcic Inferior i Mig. En arribar a Fígols d'Organyà, es fa ben palesa una ampla cubeta d'erosió, anomenada la Ribera d'Organyà, i on es situa la veïna població del mateix nom. Aquesta cubeta es troba excavada entre els materials calcolutítics del Cretàcic Inferior $\mathrm{i}$ Mig.

Precisament, des de l'indret de la parada, es pot gaudir d'un bon lloc d'observació d'aquesta cubeta. I també, tot mirant cap a l'Oest, es poden entreveure els relleus de l'Anticlinal de Bóixols (fotografia 9) i del Sinclinal de Santa Fe, donats de Sud a Nord. Aquests dos accidents formen part del Mantell de Bóixols.

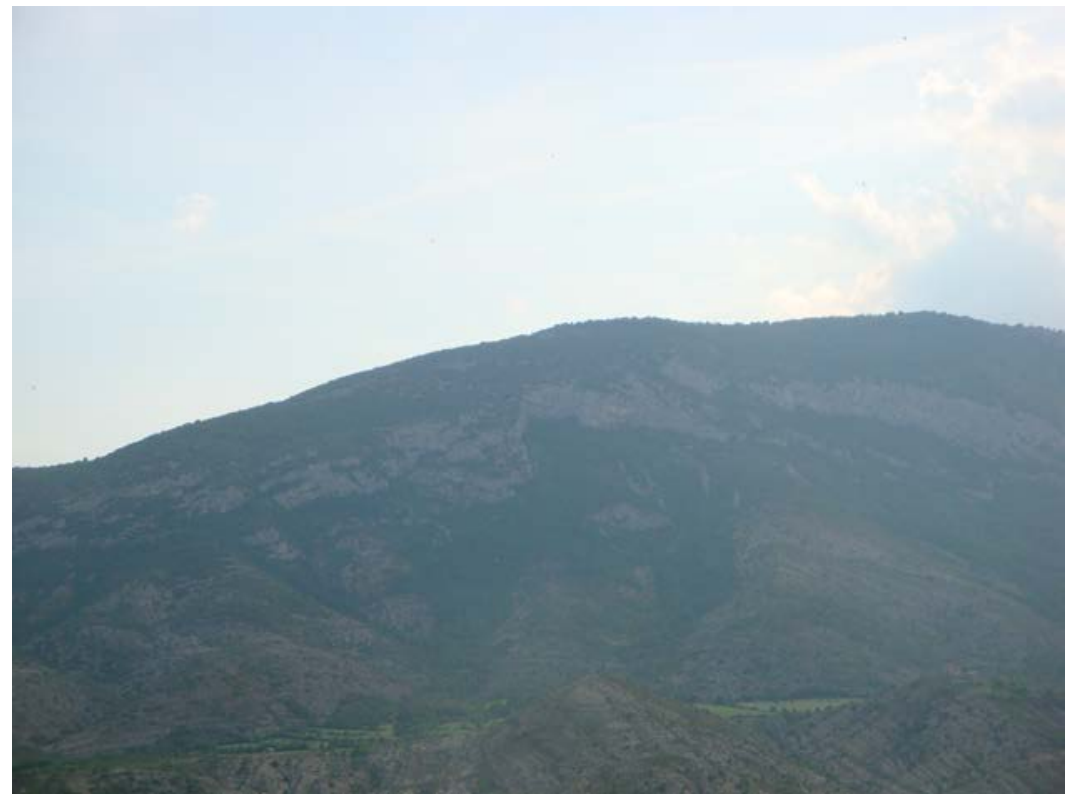

Fotografia 9. Anticlinal del Mantell de Bóixols 


\subsection{Parada 10. Carretera C - 14, Coll de Nargó, (terme de Coll de Nargó, comarca de l’Alt Urgell). (Full 253)}

Després de la parada anterior, convé retornar al Pont de l'Espia, per tal d'agafar la carretera $C$ -14, per tal d'anar cap el Sud, cap a Coll de Nargó. En arribar a les immediacions d'aquesta població farem una nova aturada, la darrera de l'itinerari, després de recórrer uns $7 \mathrm{Km}$ des de Fígols.

En aquest recorregut, hem anat trobant afloraments dels materials carbonatats del Cretàcic, els quals formen part del Mantell de Bóixols. Tot i així, en arribar a l'indret de l'aturada, podem observar un interessant contacte entre aquests materials cretàcics $i$ uns nivells calcolutítics $i$ sorrencs, que pertanyen a l'Oligocè, tot formant part del Mantell del Montsec.

Així, en aquest indret hi ha un contacte entre els dos mantells acabats d'esmentar. En aquest contacte, el de Bóixols encavalca al del Montsec, tot i que a l'indret de l'aturada no queda gaire clar. (fotografia 10).

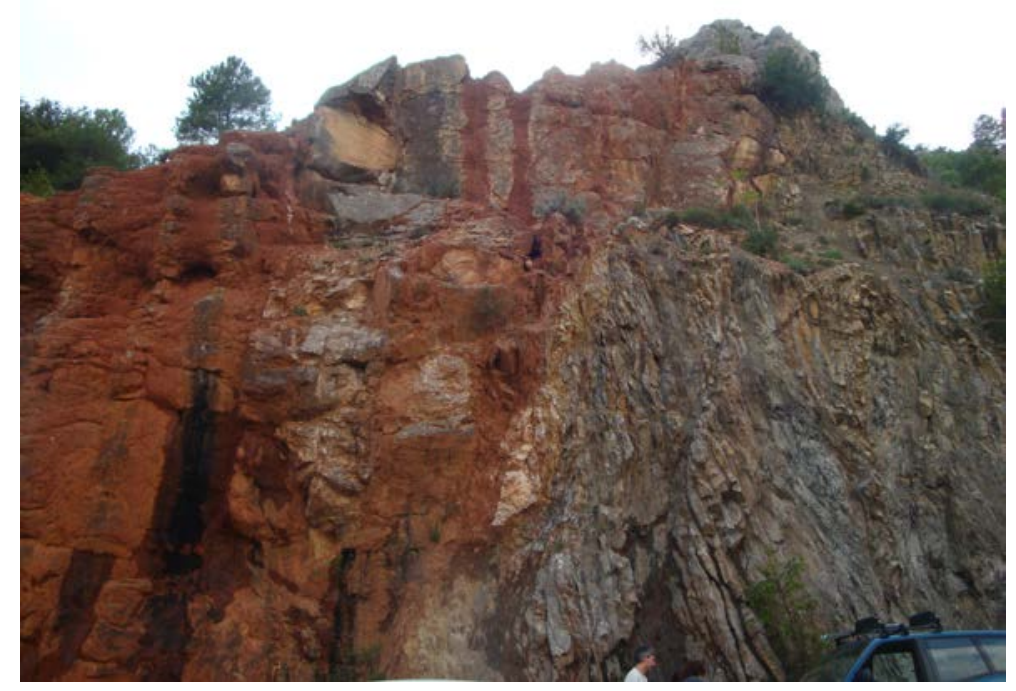

Fotografia 10. Contacte entre el Mantell de Bóixols (a la dreta) i el Mantell del Montsec (a l'esquerra)

Al mateix temps, des d'aquest indret mirant cap al NE, es pot veure un flanc de I'Anticlinal de Bóixols. En aquest cas es tracta dels afloraments situats al Sud de Fígols d’Organyà. (fotografia 11).

Tanmateix, des de l'indret de l'aturada, es pot gaudir d'una molt bona observació de l'Anticlinal d'Alinyà, que ja hem vist més d'a prop, a les primeres aturades del recorregut d'aquest itinerari.

Per d'altra banda, prop d'om hem fet la present aturada, hi ha un antic Forn de Calç, d'estructura molt interessant. Aquest indret forma part del Patrimoni Miner de la Comarca de I'Alt Urgell i alhora del conjunt de Catalunya, essent necessària la seva conservació.

En aquest indret finalitza aquest itinerari. 


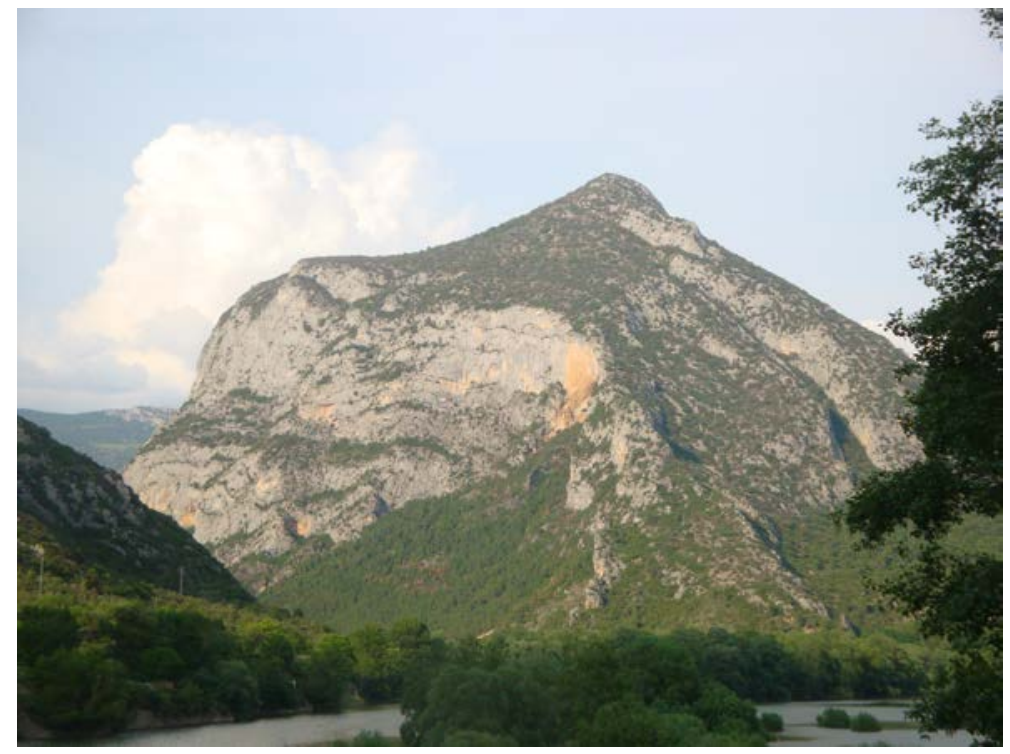

Fotografia 11. El flanc meridional del Mantell de Bóixols, prop de Fígols d’Organyà

\subsection{Bibliografia}

GUIMERÀ, J. et altri (1992).- Geologia (II), Història Natural dels Països Catalans, Vol. 2, 547 pag. Enciclopèdia Catalana, S.A. Barcelona.

MASACHS, V. et altri (1981).- Itineraris Geològics: Bages, Berguedà, Anoia i Solsonès. Pub. Centre d'Estudis Geològics "Valentí Masachs", 208 pàgines, Manresa.

MATA-PERELLÓ, J.M. (1984).- Las mineralizaciones cupríferas de la Depresión Central Catalana. Actas del 1er. Congreso Español de Geologia, t.II, pp. 588-598. Segóvia.

MATA-PERELLÓ,J.M. (1990).- Els Minerals de Catalunya. Arxius de la Secció de Ciències de I'Institut d'estudis Catalans, vol.47, 545 pàgines. Barcelona.

MATA-PERELLÓ, J.M. (1995a).- Itinerari geològico-mineralògic pel Solsonès i per I'Alt Urgell: des de Solsona a Alinyà i a Organyà. Inèdit. 12 pàgines. Manresa

MATA-PERELLÓ, J. M. (1995b).- Itinerari geològico-mineralògic per l'Alt Urgell i pel Pallars Sobirà: des d'Oliana a Noves de Segre, a la Guàrdia d'Ares i a Gerri de la Sal. Inèdit. 12 pàgines. Manresa

MATA-PERELLÓ, J.M. (1996).- Recerca geològica i mineralògica per les comarques del Solsonès i de l'Alt Urgell: des de Solsona a Alinyà, i des de Coll de Nargó a Peramola. Inèdit, 17 pag. Manresa

MATA-PERELLÓ, J.M. (1998a).- Itinerari Geològic des de Solsona a Cambrils, i des de Fígols d'Organyà a la Valldany. Xaragall, $n^{\circ} 119,19$ pag. Manresa 
MATA-PERELLÓ, J.M. (2000).- Recorregut de recerca geològica i mineralògica per les comarques del Solsonès i de I'Alt Urgell: des del Pont de Querol a Cambrils i a l'Alzina, Inèdit, 15 pag, Manresa

MATA-PERELLÓ, J.M. (1998b).- Recorregut de recerca geològica per les comarques de I'Alt Urgell (Urgell Mitjà) i del Pallars Jussà: des d'oliana a la Palanca de Noves, i des de Coll de Nargó a Isona. Inèdit. 14 pag. Manresa

MATA-PERELLÓ, J.M. (2003).- Recorregut de recerca geològica i mineralògica des del Pont de Querol a Cambrils i a l'Alzina (per les comarques del Solsonès i de I'Alt Urgell). Inèdit. 10 pag. Manresa

MATA-PERELLÓ, J.M. (2004).- Recorregut de recerca geològica i mineralògica per la comarca del Solsonès (tot fent una fillola final per la de l'Alt Urgell). des del Pont de Querol a Cambrils i a Santa Pellaia. Inèdit 10 pag. Manresa

MATA-PERELLÓ, J.M. (2005).- Recorregut de recerca geològica i mineralògica per les comarques del Solsonès i de l'Alt Urgell: des del Pont de Querol a Cambrils, l'Alzina i Organyà. Inèdit. 12 pag. Manresa 